\title{
Evaluation of Soil Properties under the Effect of Organic Mulches in Acid Lime (Citrus aurantifolia Swingle)
}

\author{
Esther Lalruatsangi ${ }^{*}$, B.N. Hazarika ${ }^{1}$, A.S. Mailappa ${ }^{2}$ and R. Lalnungrenga ${ }^{3}$ \\ ${ }^{1}$ Department of Fruit Science, ${ }^{2}$ Department of Natural Resource Management, \\ College of Horticulture and Forestry, Central Agricultural University, Pasighat, \\ Arunachal Pradesh, India \\ ${ }^{3}$ Department of Silviculture and Forest Management, Forest Research Institute, \\ Dehradun, Uttarakhand, India
}

*Corresponding author

\section{A B S T R A C T}

\section{Keywords}

Acid lime, Organic mulching, Soil properties

Article Info

Accepted:

17 October 2019

Available Online:

10 November 2019
An experiment was conducted at Fruit Research Farm, College of Horticulture and Forestry, Pasighat, Arunachal Pradesh to study the effect of organic mulches on soil properties in acid lime using Randomized Block Design. The study revealed that the soil properties were found to be highly significant. The maximum soil moisture content $(33.66 \%)$ was observed in dry grasses mulch (T1) while maximum organic carbon $(3.11 \%)$, available nitrogen $(428.47 \mathrm{~kg} / \mathrm{ha})$, available phosphorus $(45.17 \mathrm{~kg} / \mathrm{ha})$ and potassium $(575.06 \mathrm{~kg} / \mathrm{ha})$ were observed in saw dust mulch (T6) (Table 1). The mulching materials especially paddy straw and rice husk mulch imparted significance increase on the soil microbial population. Paddy straw mulch (T3) recorded highest microbial population of bacteria at $83.45 \times 10^{\text {s }}$ followed by rice husk mulch (T4) at $74.88 \times 10^{5}$ while highest population of fungi was observed in rice husk mulch (T4) at $119.34 \times 10^{\text {s }}$ followed by paddy straw mulch $(\mathrm{T} 3)$ at $54.77 \times 10$.

\section{Introduction}

Acid lime (Citrus aurantifolia Swingle) belongs to the family Rutaceae, having a chromosome number of $2 \mathrm{n}=18$ and is considered to be indigenous to India. It is the third important citrus fruit crop in India next to mandarin and sweet orange. The fruit is valued not only for its nutritional qualities but also for pharmaceutical, nutraceutical, cosmeceutical, medicinal and health sector with its great potential growth. Mulching 
plays an important role in conservation of soil moisture during dry periods, as well as improves physical, biological and chemical properties of soil. Mulching is a practice, which helps in proper growth and development of the plants by modifying soil temperature, providing better nutrient availability and by better moisture conservation (Kher et al., 2010). Research has shown that organic mulch provides many benefits to crop production through soil and water conservation enhance soil biological activity and improve chemical and physical properties of the soil (Bhardwaj, 2013). Organic mulches add nutrients and humus to the soil as they decompose, improving its tilth and moisture holding capacity (Bakshi et al., 2015) which includes increased mineralization rates, suppress diseases and nutrient cycling (Pinamonti, 1998).

Studies indicate that the addition of organic mulches decreased the fertilizer requirements (Evanylo et al., 2008), decreased soil bulk density, and increased soil carbon and cation exchange capacity (Tiquia et al., 2002).

However, the advantageous effects of the organic mulching materials on soil properties have not been studied in acid lime. Therefore, an evaluation of soil properties was done to find out the effect of locally available organic mulching materials in acid lime.

\section{Materials and Methods}

The experiment was carried out on 6 years old acid lime var. PKM 1 planted at spacing of $3 \mathrm{~m}$ $\times 3 \mathrm{~m}$ at Fruit Research Farm, College of Horticulture and Forestry, Central Agricultural University, Pasighat. Arunachal Pradesh.

The experiment consisted of six treatments in a Randomized Block design with three replications. The organic mulching treatments were $\mathrm{T} 1=$ Dry grasses, $\mathrm{T} 2=$ Banana leaves, $\mathrm{T} 3$
$=$ Paddy straw, T4 $=$ Rice husk, $\mathrm{T} 5=$ Wood shavings and T6 $=$ Saw dust. The surface $(0-15$ $\mathrm{cm})$ soil samples were used for analyzing the soil properties. The soil properties were determined using soil analytical methods given by Jackson (1973) as organic carbon content was determined by wet digestion method of Walkley and Black, available nitrogen $(\mathrm{N})$ by Kjeldahl's method, available phosphorous (P) by Bray and Kurtz method and available potassium (K) by flame photometric method. The microbial population of the soil was estimated using serial dilution agar plating method or viable plate count method.

\section{Results and Discussion}

The effect of organic mulching materials on soil moisture content, organic carbon, available nitrogen, phosphorus, potassium content and microbial population have been observed showing a significant observation although there was no significant impact on the soil $\mathrm{pH}$. The maximum soil moisture content $(33.66 \%)$ was observed in dry grasses mulch (T1) while maximum organic carbon (3.11\%), available nitrogen (428.47 kg/ha), available phosphorus (45.17 $\mathrm{kg} / \mathrm{ha})$ and potassium $(575.06 \mathrm{~kg} / \mathrm{ha})$ were observed in saw dust mulch (T6) (Table 1). The mulching materials especially paddy straw and rice husk mulch imparted significance increase on the soil microbial population. Paddy straw mulch (T3) recorded highest microbial population of

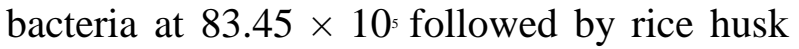
mulch (T4) at $74.88 \times 10^{5}$ while highest population of fungi was observed in rice husk

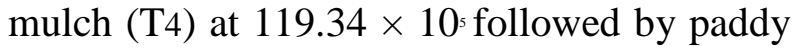
straw mulch (T3) at $54.77 \times 10$. The available nitrogen in post harvest soils increased successively with increasing nitrogen levels which was due to integration of organic and inorganic sources and also due to increased microbial activity which could have stimulated the nitrification process. 
Table.1 Effect of organic mulching materials on soil properties

\begin{tabular}{|c|c|c|c|c|c|c|c|c|}
\hline \multirow[t]{2}{*}{ Treatments } & \multirow[t]{2}{*}{ Soil pH } & \multirow{2}{*}{$\begin{array}{c}\text { Soil } \\
\text { moisture } \\
\text { content } \\
(\%)\end{array}$} & \multirow{2}{*}{$\begin{array}{c}\text { Organic } \\
\text { carbon } \\
(\%)\end{array}$} & \multirow{2}{*}{$\begin{array}{c}\text { Available } \\
\text { nitrogen } \\
(\mathrm{kg} / \mathrm{ha})\end{array}$} & \multirow{2}{*}{$\begin{array}{c}\text { Available } \\
\text { phosphorus } \\
\text { (kg/ha) }\end{array}$} & \multirow{2}{*}{$\begin{array}{c}\text { Available } \\
\text { potassium } \\
\text { (kg/ha) }\end{array}$} & \multicolumn{2}{|c|}{$\begin{array}{c}\text { Microbial } \\
\text { population }(\mathrm{cfu} / \mathrm{g})\end{array}$} \\
\hline & & & & & & & $\begin{array}{c}\text { Bacteria } \\
\left(\times 10^{5}\right)\end{array}$ & $\begin{array}{l}\text { Fungi } \\
\left(\times 10^{5}\right)\end{array}$ \\
\hline $\mathbf{T}_{1}$ & 5.37 & 33.66 & 2.85 & 388.80 & 44.80 & 511.46 & 29.42 & 0.10 \\
\hline $\mathbf{T}_{2}$ & 5.41 & 29.11 & 2.49 & 347.10 & 31.73 & 482.16 & 27.36 & 0 \\
\hline $\mathbf{T}_{3}$ & 5.53 & 30.26 & 3.03 & 367.63 & 41.81 & 556.92 & 83.45 & 54.77 \\
\hline $\mathbf{T}_{4}$ & 5.32 & 28.66 & 2.94 & 376.27 & 42.93 & 559.35 & 74.88 & 119.34 \\
\hline $\mathbf{T}_{5}$ & 5.97 & 26.73 & 2.76 & 409.73 & 38.08 & 527.86 & 31.89 & 0.25 \\
\hline $\mathrm{T}_{6}$ & 5.90 & 29.66 & 3.11 & 428.47 & 45.17 & 575.06 & 34.77 & 0.03 \\
\hline SEd ( $( \pm)$ & - & 2.99 & 0.21 & 33.98 & 5.96 & 32.17 & 1.14 & 0.18 \\
\hline CD at $5 \%$ & N.S & 6.34 & 0.44 & 72.03 & 12.65 & 68.21 & 2.43 & 0.38 \\
\hline
\end{tabular}

Among the organic mulches, saw dust mulch (T6) proves to have a profound beneficial effect on the soil properties although the other treatments were in par with $\mathrm{T} 6$.

The experimental study concluded that organic mulching materials had significantly influenced moisture conservation, nutrient $\mathrm{N}: \mathrm{P}: \mathrm{K}$ concentration and soil health in acid lime. The moisture regulation is of utmost importance and needs to be emphasized as a priority at critical stages of growth.

\section{References}

Bakshi, P., V. K. Wali, M. Iqbal, A. Jasrotia, K. Kour, R. Ahmed and M. Bakshi, "Sustainable fruit production by soil moisture conservation with different mulches- A review" in African Journal of Agricultural Research, 10th ed. Vol.52. 2015, pp. 4718-4729.

Bhardwaj, R. L., Effect of mulching on crop production under rainfed condition- A review in Agriculture Reviews. 34th ed. Vol. 3, 2013, pp. 188-197.

Evanylo, G., C. Sherony, J. Spargo, D. Starner, M. Brosius and K. Haering, "Soil and water environmental effects of fertilizer-, manure-, and compostbased fertility practices in an organic vegetable cropping system" in Agriculture, Ecosystems and Environment. 127th ed. 2008, pp. 5058.

Jackson, M. L. Soil chemical analysis. Prentice Hall of India Private Limited, New Delhi. 1973.

Kher, R., J A. Baba and P. Bakshi. "Influence of planting time and mulching material on growth and fruit yield of strawberry cv. Chandler" in Indian Journal of Horticulture. 67th ed. Vol. 4. 2010, pp. 441-444.

Pinamonti, F.1998. "Compost mulch effects on soil fertility, nutrition status and performance of grapevine" in Nutrient Cycling in Agroecosystems. 51th ed., pp. 239-248.

Tiquia, S. M., J. Lloyed, D. A. Herms and H.A. J. Hoitink "Effects of mulching and fertilization on soil nutrients, microbial activity and rhizosphere bacterial community structure determined by analysis of TRFLPs of PCR amplifications 16S rRNA genes" in Applied Soil Ecology. 21th ed. 2002, pp. 31-48. 


\section{How to cite this article:}

Esther Lalruatsangi, B.N. Hazarika, A.S. Mailappa and Lalnungrenga, R. 2019. Evaluation of Soil Properties under the Effect of Organic Mulches in Acid Lime (Citrus aurantifolia Swingle). Int.J.Curr.Microbiol.App.Sci. 8(11): 1743-1744. doi: https://doi.org/10.20546/ijcmas.2019.811.203 